\title{
EXPERIMENTS ON ADDITIVE DESULPHURISATION BY SODIUM BICARBONATE IN COAL-FUEL BOILERS
}

\author{
Pavel Kolat*, Bohumír Čech, Mojmír Vrtek, David Tomášek \\ VŠB - Technical University of Ostrava, 17. listopadu 15, 70833 Ostrava, Czech Republic
}

\begin{abstract}
This paper describes experiments on the application of sodium bicarbonate desulphurisation in the coal-fuel boiler. The boiler has been in operation for several years now and it has refiably fulfilled the original assignment to reduce SO2 emissions from the value of $1200-1500 \mathrm{mg} / \mathrm{Nm}^{3}$ to $400 \mathrm{mg} / \mathrm{Nm}^{3}$. Higher desulphurisation efficiency is determined only by the ratio of $\mathrm{Na} / \mathrm{S}$ sorbent dosage. The resulting product of desulphurisation is stored together with fly ash in underground mines, and has no influence on the groundwater. Positive experience of the tests and boiler operation lies in higher reactivity of sodium and sulphur as compared with conventional methods based on limestone. Within the scope of the secondary measures of elimination of sulphur oxides in combustion products, an experimental dry-method desulphurisation of combustion products was performed by blasting an agent containing sodium bicarbonate $\mathrm{NaHCO} 3(99.6 \%)$ into the flue ways before the electrostatic precipitator in a coal-fuel furnace with the steam output of $220 \mathrm{t} / \mathrm{h}$.
\end{abstract}

Keywords: combustion, desulphurisation, pulverised, bicarbonate

\section{INTRODUCTION}

Calcium-based methods have a limited use of the desulphurisation product. Gypsum as calcium sulphate $\mathrm{CaSO}_{4}$ is essentially hazardous waste and requires a special storage mode. In this situation the use of additive desulphurisation and other chemical compounds is better than calcium. Desulphurisation by sodium bicarbonate includes a process of thermal activation triggered by sodium bicarbonate interaction with hot combustion products. Sodium bicarbonate is at this stage immediately transformed into carbonate. Carbonate is very porous and has a large specific surface. The surface of newly generated carbonates is a very good sorbent of heavy metals and PCDD/F. The desulphurisation process can be described by the following equations:

$$
\begin{gathered}
\left.2 \mathrm{NaHCO}_{3}+\text { ( heat }\right) \Rightarrow \mathrm{Na}_{2} \mathrm{CO}_{3}+\mathrm{CO}_{2}+\mathrm{H}_{2} \mathrm{O} \\
2 \mathrm{NaHCO}_{3}+\mathrm{SO}_{2}+1 / 2 \mathrm{O}_{2} \Rightarrow \mathrm{Na}_{2} \mathrm{SO}_{4}+\mathrm{H}_{2} \mathrm{O}+2 \mathrm{CO}_{2} \\
\mathrm{NaHCO}_{3}+\mathrm{HCl} \Rightarrow \mathrm{NaCl}+\mathrm{H}_{2} \mathrm{O}+2 \mathrm{CO}_{2} \\
\mathrm{NaHCO}_{3}+\mathrm{HF} \Rightarrow \mathrm{NaF}+\mathrm{H}_{2} \mathrm{O}+2 \mathrm{CO}_{2}
\end{gathered}
$$

Sodium bicarbonate is a hydroscopic substance and it tends to paste when fine ground (it is supplied as coarse grained and then ground to the required grain size immediately before dosing). 
Advantages: High desulphurisation efficiency, possible elimination of nitrogen oxides (only chemical consideration), financially and technically undemanding application of sodium bicarbonate (Halstead and Raask, 1969; Joutsenoja, 1998).

Disadvantages: High costs connected with the use of sodium bicarbonate (the price of the agent), deposition of sodium sulphate $\left(\mathrm{Na}_{2} \mathrm{SO}_{4}\right)$ based products of desulphurisation (the largest and financially the most costly part).

The principle of the whole method of elimination of sulphur oxides (Szeliga et al., 2008) from combustion products is blasting ground sodium bicarbonate to the flue way before the two-stage electrostatic fly ash precipitator (the blasting location is shown in Fig. 1) with subsequent measurement of gaseous emissions and combustion product flow. The measurement of gaseous emissions was performed behind the flue exhauster as well as before the $\mathrm{NaHCO}_{3}$ based agent inlet (see Fig. 1), that is at the outlet of the combustion gases from the furnace. Desulphurisation tests carried out at the furnace steam outputs of $110 \mathrm{t} / \mathrm{h}, 160 \mathrm{t} / \mathrm{h}$, and $180 \mathrm{t} / \mathrm{h}$, with the use of two types of the input fuel, i.e. black coal and a mixture of black coal and shed coal. Individual tests are described in Table 1.

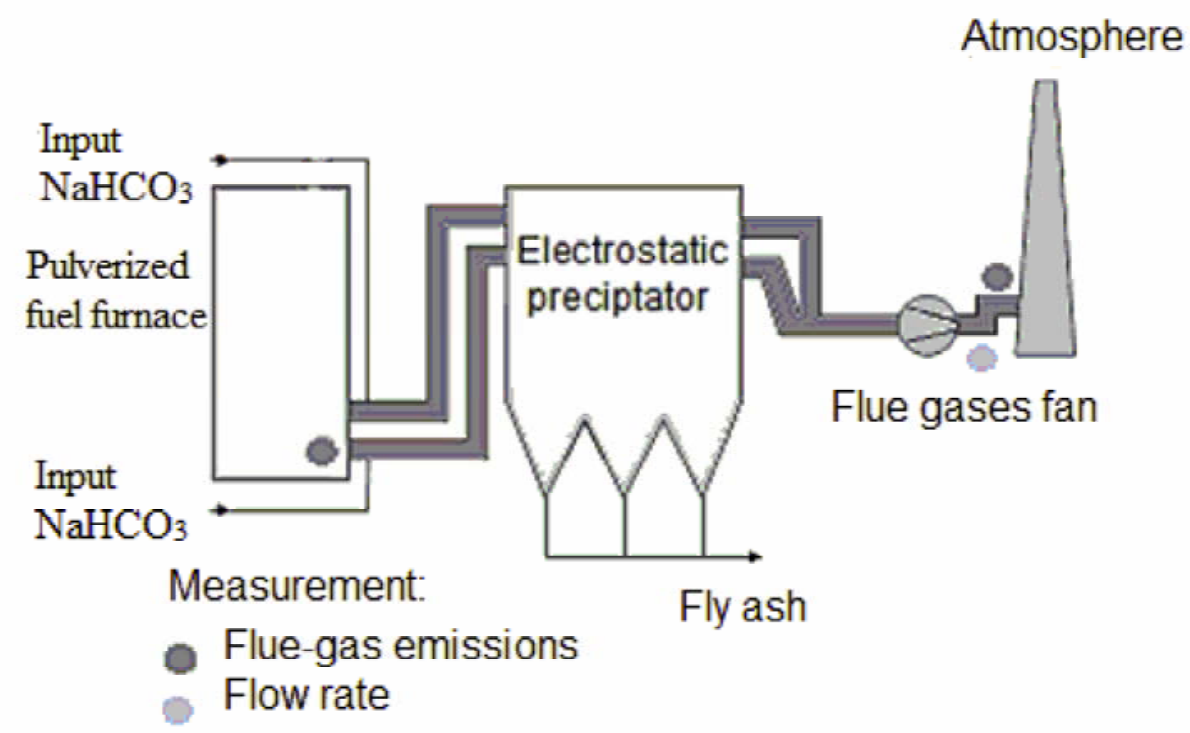

Fig. 1. $\mathrm{NaHCO}_{3}$ unit

Table 1. List of desulphurisation tests

\begin{tabular}{|c|c|c|c|}
\hline Date & Furnace output $[\mathrm{t} / \mathrm{h}]$ & Fuel & $\begin{array}{c}\text { Combustion } \\
\text { product flow } \\
{\left[\mathrm{Nm}^{3} / \mathrm{h}\right]}\end{array}$ \\
\hline 10.10. & 110 & pulverised fuel & 152100 \\
\hline 11.10. & 110 & pulverised fuel + shed coal & 145616 \\
\hline 15.10. & 180 & pulverised fuel + shed coal & 271944 \\
\hline 16.10. & 180 & pulverised fuel + shed coal & 269495 \\
\hline 17.10. & 180 & pulverised fuel + shed coal & 261538 \\
\hline 18.10. & 160 & pulverised fuel + shed coal & 220991 \\
\hline 19.10. & 180 & pulverised fuel + shed coal & 274244 \\
\hline 22.10. & 180 & pulverised fuel + shed coal & 258106 \\
\hline 23.10. & 180 & pulverised fuel + shed coal & 265112 \\
\hline
\end{tabular}


The experimental desulphurisation tests were carried out at a pulverised-fuel furnace with a liquid slag chamber and with the steam output of $220 \mathrm{t} / \mathrm{h}$ and the nominal output of $161 \mathrm{MW}$. The temperature ranged from 165 to $195{ }^{\circ} \mathrm{C}$. The $\mathrm{SO}_{2}$ emissions represent min. $550 \mathrm{mg} / \mathrm{Nm}^{3}$, max. $1000 \mathrm{mg} / \mathrm{Nm}^{3}$, and the average concentration amounted to $650 \mathrm{mg} / \mathrm{Nm}^{3}$. The average concentration of $\mathrm{SO}_{2}$ during the experimental tests was $747 \mathrm{mg} / \mathrm{Nm}^{3}$. The measurement methods and workplace equipments conforms to current requirements for chemical diagnostic methods. The research team is a part of accredited testing laboratory staff ( $\mathrm{CZ}$ no. 1588).

Black coal was used in a one-day desulphurisation test only. During the remaining 9 days of tests a mixture consisting of black coal and shed coal was used. The chemical analyses of black coal and shed coal are stated in Table 2 and Table 3.

Table 2. Black coal parameters

\begin{tabular}{|l|c|c|}
\hline \multicolumn{1}{|c|}{ Name } & Marking & Value \\
\hline Calorific value & {$[\mathrm{MJ} / \mathrm{kg}]$} & 23.0 \\
\hline Ash content & {$[\%]$} & 14 \\
\hline Sulphur content & {$[\%]$} & $0.3-0.5$ \\
\hline Water content & {$[\%]$} & $8-10$ \\
\hline
\end{tabular}

Table 3. Black coal / shed coal mix parameters

\begin{tabular}{|l|c|c|}
\hline \multicolumn{1}{|c|}{ Name } & Marking & Value \\
\hline Calorific value & {$[\mathrm{MJ} / \mathrm{kg}]$} & 18.0 \\
\hline Ash content & {$[\%]$} & $44-46$ \\
\hline Combustible volatile share & {$[\%]$} & $31-34$ \\
\hline Ash softening temperature & {$\left[{ }^{\circ} \mathrm{C}\right]$} & 1300 \\
\hline Ash fusing point & {$\left[{ }^{\circ} \mathrm{C}\right]$} & 1445 \\
\hline Ash flow point & {$\left[{ }^{\circ} \mathrm{C}\right]$} & 1505 \\
\hline Sulphur content & {$[\%]$} & $0.3-0.5$ \\
\hline Water content & {$[\%]$} & $6-10$ \\
\hline
\end{tabular}

The dry method of elimination of sulphur oxides from the combustion products in the furnace with the maximum steam output of $220 \mathrm{t} / \mathrm{h}$, was carried out with the use of a sodium bicarbonate $\left(\mathrm{NaHCO}_{3}\right)$ based agent. The agent contained $99.6 \%$ of sodium bicarbonate and its specific weight was $1.1-1.3 \mathrm{~kg} / \mathrm{dm}^{3}$. The $\mathrm{NaHCO}_{3}$ based agent was supplied to the test site in 1 ton transport bags and it was then ground to the required grain size of $\mathrm{d} 90 \leq 20 \mu \mathrm{m}$ using an experimental grinding unit with the rated output of $30 \mathrm{~kW}$. The main objective of the experimental desulphurisation method (Galos et al., 2003) was to demonstrate that it is possible to eliminate $\mathrm{SO}_{2}$ concentrations in combustion products and maintain the residual content of $\mathrm{SO}_{2}$ below $200 \mathrm{mg} / \mathrm{mg} / \mathrm{Nm}^{3}$ with the use of other than the established methods based on exploitation of lime. The procedure of reduction of concentration of $\mathrm{SO}_{2}$ in combustion gases was assigned in three theoretical levels of desulphurisation efficiency, $20 \%, 40 \%$, $60 \%$ and the maximum volume possible with regard to the maximum possible output of the mobile grinding unit. The experimental desulphurisation tests were carried out in the steam output levels of $110 \mathrm{t} / \mathrm{h}, 160 \mathrm{t} / \mathrm{h}$, and $180 \mathrm{t} / \mathrm{h}$ in order to provide simulation of an actual operation. The duration of the experiment was 9 days and it was performed in the conditions of steady operation. The volume of the agent necessary to achieve the required desulphurisation efficiency was calculated in accordance with the stoichiometric balance (i.e. the known concentration of $\mathrm{SO}_{2}$ in the raw combustion products, 
theoretical efficiency, and the stoichiometric ratio of $2 \mathrm{NaHCO}_{3} / \mathrm{SO}_{2}$ ) plus the final expert assessment. Continuous measurement of the $\mathrm{SO}_{2}$ outlet gaseous emissions was conducted during each desulphurisation test including fly ash sampling from the right and the left section of the electrostatic separator. The samples were supplied for chemical analyses.

\section{EXPERIMENTAL TESTS}

The first desulphurisation test was conducted at the steam output level of $110 \mathrm{t} / \mathrm{h}$ within a two-day period. The aim of the desulphurisation tests was to achieve the theoretical efficiency of $20 \%, 40 \%$, and $60 \%$. The initial fuel was black coal and for the remaining part of the test, which was carried out at the output level of $110 \mathrm{t} / \mathrm{h}$, a mixture of black coal and shed coal was used. The development and the results of the two-day tests are presented in Table 4 and Fig. 2.

The concentration of $\mathrm{SO}_{2}$ emissions was measured before and after the point of sorbent dosage. The flue gases pass through an electrostatic precipitator, where the ash from the boiler and reacted sorbent are captured in a form of sodium sulphate. After cleaning, the flue gases flow into the fan, where they are thoroughly mixed for analysis of the gaseous samples. The sampling site was located at the outlet of the flue gas fan, before entering the chimney. Measurements were carried out by the continuous analysers Hartmann Braun, Uras and Magnos based on the absorption principle in the infrared radiation. The measurement accuracy is determined by the type of device and the monitored gas. In general it can be stated that the accuracy of the $\mathrm{SO}_{2}$ measurements by the continuous measurement analysers with calibration gas mixtures is around $+/-3 \%$ of calibrated span. Measurements were controlled by means of operating instruments and other independent analysers. The $\mathrm{SO}_{2}$ concentration is determined before desulphurisation by means of combustible sulphur content in the fuel and it can not be changed. The sulphur concentration at the outlet was measured by means of two instruments. Each measurement method is burdened with a certain error. In the case of measuring the concentration of $\mathrm{SO}_{2}$, sample after condensation it is slightly acidic. Passage of the fine fraction to the sample may affect the measured values. These changes are not essential.

Table 4. Results of desulphurisation of combustion gases $-110 \mathrm{t} / \mathrm{h}$ steam output

\begin{tabular}{|c|c|c|c|c|c|c|c|}
\hline Date & Test No. & $\begin{array}{l}\text { Desulphurisation } \\
\text { target value }\end{array}$ & $\begin{array}{c}\text { Flow rate } \\
\mathrm{NaHCO}_{3} \\
{[\mathrm{~kg} / \mathrm{h}]} \\
\end{array}$ & $\begin{array}{c}\mathrm{SO}_{2} \\
{\left[\mathrm{mg} / \mathrm{Nm}^{3}\right]}\end{array}$ & $\begin{array}{c}\mathrm{HCl} \\
{\left[\mathrm{mg} / \mathrm{Nm}^{3}\right]}\end{array}$ & $\begin{array}{c}\text { Capture } \\
{\left[\mathrm{mg} / \mathrm{Nm}^{3}\right]} \\
\mathrm{SO}_{2}\end{array}$ & $\begin{array}{c}\text { Actual } \\
\mathrm{SO}_{2}[\%]\end{array}$ \\
\hline \multirow{4}{*}{$\stackrel{\dot{0}}{\ddot{0}}$} & 1 & $0 \%$ & 0 & 704 & 60 & 0 & $0 \%$ \\
\hline & 2 & $20 \%$ & 100 & 539 & 22 & 165 & $23 \%$ \\
\hline & 3 & $40 \%$ & 180 & 411 & 12 & 293 & $42 \%$ \\
\hline & 4 & $60 \%$ & 280 & 312 & 7 & 392 & $56 \%$ \\
\hline \multirow{8}{*}{$\begin{array}{l}\dot{0} \\
= \\
=\end{array}$} & 5 & $0 \%$ & 0 & 728 & 63 & 0 & $0 \%$ \\
\hline & 6 & $20 \%$ & 105 & 517 & 14 & 211 & $29 \%$ \\
\hline & 7 & $40 \%$ & 195 & 399 & 6 & 329 & $45 \%$ \\
\hline & 8 & $60 \%$ & 285 & 303 & 4 & 425 & $58 \%$ \\
\hline & 9 & $0 \%$ & 0 & 739 & 50 & 0 & $0 \%$ \\
\hline & 10 & $20 \%$ & 100 & 552 & 15 & 187 & $25 \%$ \\
\hline & 11 & $40 \%$ & 185 & 452 & 7 & 287 & $39 \%$ \\
\hline & 12 & $60 \%$ & 300 & 318 & 3 & 421 & $57 \%$ \\
\hline
\end{tabular}




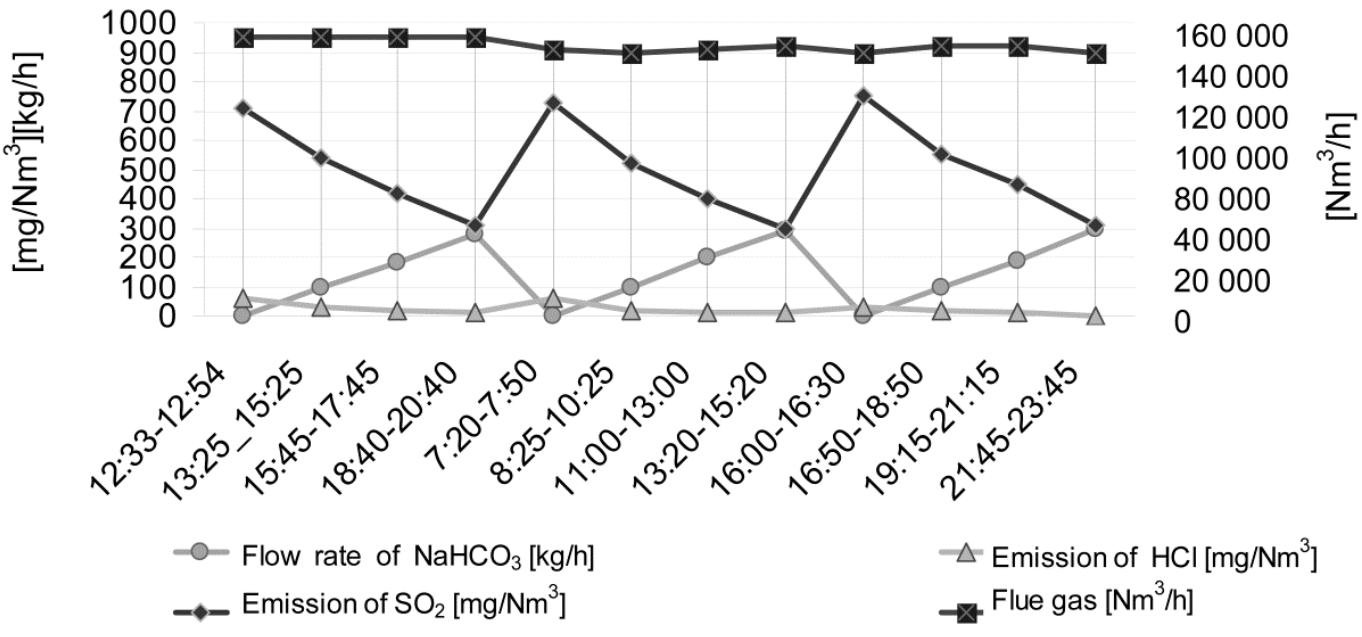

Fig. 2. Desulphurisation test results $-110 \mathrm{t} / \mathrm{h}$

During the experiment the steam output of the furnace was increased to $160 \mathrm{t} / \mathrm{h}$ and a test was carried out with the goal to achieve the theoretical desulphurisation efficiency of $60 \%$. The fuel used was a mixture of black coal and shed coal. The development and the results of the one-day desulphurisation test are presented in Table 5. and Fig. 3.

Table 5. Results of desulphurisation of combustion gases $-110 \mathrm{t} / \mathrm{h}$ steam output

\begin{tabular}{|c|c|c|c|c|c|c|c|}
\hline Date & $\begin{array}{c}\text { Test } \\
\text { No. }\end{array}$ & $\begin{array}{c}\text { Desulphuri- } \\
\text { sation target } \\
\text { value }\end{array}$ & $\begin{array}{c}\text { Flow rate } \\
\mathrm{NaHCO}_{3} \\
{[\mathrm{~kg} / \mathrm{h}]}\end{array}$ & $\begin{array}{c}\mathrm{SO}_{2} \\
\text { concent. } \\
{\left[\mathrm{mg} / \mathrm{Nm}^{3}\right]}\end{array}$ & $\begin{array}{c}\mathrm{HCl} \\
{\left[\mathrm{mg} / \mathrm{Nm}^{3}\right]}\end{array}$ & $\begin{array}{c}\text { Capture } \\
{\left[\mathrm{mg} / \mathrm{Nm}^{3}\right]} \\
\mathrm{SO}_{2}\end{array}$ & $\begin{array}{c}\text { Actual elim. } \\
\mathrm{SO}_{2}[\%]\end{array}$ \\
\hline \multirow{2}{*}{$\underset{\infty}{\stackrel{\infty}{\infty}}$} & 25 & $0 \%$ & 0 & 780 & 58 & 0 & $0 \%$ \\
\cline { 2 - 8 } & 26 & $60 \%$ & 530 & 284 & 1 & 496 & $98 \%$ \\
\cline { 2 - 8 } & 27 & $60 \%$ & 523 & 302 & 1 & 478 & $98 \%$ \\
\hline
\end{tabular}
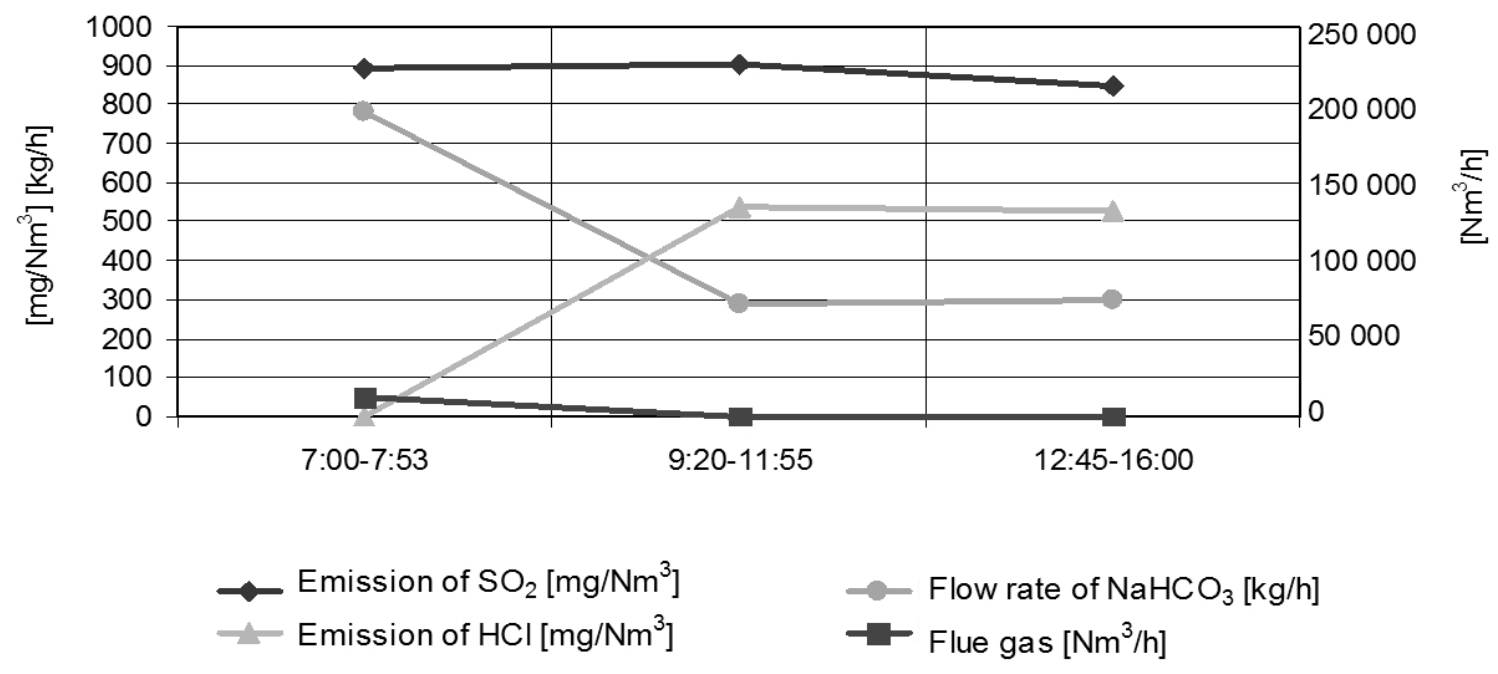

Fig. 3. Desulphurisation test results $-160 \mathrm{t} / \mathrm{h}$ 
The experimental desulphurisation tests were further conducted at an increased steam output of $180 \mathrm{t} / \mathrm{h}$. This test was performed with the maximum volume of the $\mathrm{NaHCO}_{3}$ based agent. It was limited by the design and the maximum possible output of the mobile grinding unit. The tests at the steam output level had the longest time flow and were carried out over a six-day period. The fuel was a mixture of black coal and shed coal. The aim of the desulphurisation tests, apart from the already mentioned maximum volume of agent blasting, was to reach the theoretical efficiency amounting to $20 \%, 40 \%$, and $60 \%$. The development and the results of the one day desulphurisation test are presented in Table 6 and Fig. 4.

Table 6. Results of desulphurisation of combustion gases $-180 \mathrm{t} / \mathrm{h}$ steam output

\begin{tabular}{|c|c|c|c|c|c|c|c|}
\hline Date & $\begin{array}{l}\text { Test } \\
\text { No. }\end{array}$ & $\begin{array}{l}\text { Desulphurisa- } \\
\text { tion target } \\
\text { value }\end{array}$ & $\begin{array}{c}\text { Flow } \\
\text { rate } \\
\mathrm{NaHCO}_{3} \\
{[\mathrm{~kg} / \mathrm{h}]}\end{array}$ & $\begin{array}{c}\mathrm{SO}_{2} \\
{\left[\mathrm{mg} / \mathrm{Nm}^{3}\right]}\end{array}$ & $\begin{array}{c}\mathrm{HCl} \\
{\left[\mathrm{mg} / \mathrm{Nm}^{3}\right]}\end{array}$ & $\begin{array}{c}\text { Capture } \\
{\left[\mathrm{mg} / \mathrm{Nm}^{3}\right]} \\
\mathrm{SO}_{2}\end{array}$ & $\begin{array}{c}\text { Actual elim. } \\
\mathrm{SO}_{2}[\%]\end{array}$ \\
\hline \multirow{3}{*}{$\begin{array}{l}\dot{0} \\
\ddot{n}\end{array}$} & 13 & $0 \%$ & 0 & 724 & 60 & 0 & $0 \%$ \\
\hline & 14 & $60 \%$ & 453 & 263 & 0 & 461 & $64 \%$ \\
\hline & 15 & $60 \%$ & 453 & 339 & 2 & 385 & $53 \%$ \\
\hline \multirow{7}{*}{ 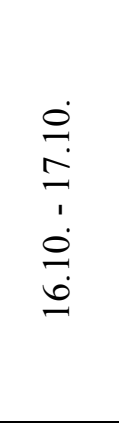 } & 16 & $0 \%$ & 0 & 715 & 53 & 0 & $0 \%$ \\
\hline & 18 & $20 \%$ & 150 & 554 & 8 & 161 & $23 \%$ \\
\hline & 19 & $40 \%$ & 297 & 392 & 2 & 323 & $45 \%$ \\
\hline & 17 & $20 \%$ & 150 & 535 & 9 & 180 & $25 \%$ \\
\hline & 20 & $0 \%$ & 0 & 746 & 62 & 0 & $0 \%$ \\
\hline & 21 & $40 \%$ & 300 & 438 & 3 & 308 & $41 \%$ \\
\hline & 22 & $60 \%$ & 476 & 338 & 2 & 408 & $55 \%$ \\
\hline \multirow{3}{*}{$\stackrel{0}{\check{1}}$} & 20 & $0 \%$ & 0 & 746 & 62 & 0 & $0 \%$ \\
\hline & 23 & $\max$ & 1015 & 145 & 2 & 601 & $81 \%$ \\
\hline & 24 & $\max$ & 1206 & 106 & 2 & 640 & $86 \%$ \\
\hline \multirow{3}{*}{$\stackrel{\dot{0}}{a}$} & 28 & $0 \%$ & 0 & 780 & 57 & 0 & $0 \%$ \\
\hline & 29 & $40 \%$ & 340 & 454 & 3 & 326 & $42 \%$ \\
\hline & 30 & $60 \%$ & 548 & 323 & 1 & 457 & $59 \%$ \\
\hline \multirow{2}{*}{22.10} & 31 & $0 \%$ & 0 & 813 & 53 & 0 & $0 \%$ \\
\hline & 32 & $60 \%$ & 496 & 307 & 1 & 506 & $62 \%$ \\
\hline \multirow{2}{*}{23.10 . } & 33 & $0 \%$ & 0 & 747 & 52 & 0 & $0 \%$ \\
\hline & 34 & $40 \%$ & 280 & 426 & 2 & 321 & $43 \%$ \\
\hline
\end{tabular}

\section{DISCUSSION}

The main objective of the experimental desulphurisation tests was reduction of concentrations of sulphur oxides below the value of $200 \mathrm{mg} / \mathrm{Nm}^{3}$ by dosing the sodium bicarbonate $\left(\mathrm{NaHCO}_{3}\right)$ based agent into the flue ways, i.e. performing the dry additive method by a different chemical agent than is the commonly established lime $\mathrm{CaCO}_{3}$ (Lindner and Wall, 1990; Meij et al., 1984). The initial part of the tests was performed at the steam output level of $110 \mathrm{t} / \mathrm{h}$ within a two-day period and with the theoretically determined efficiency of $20 \%, 40 \%$, and $60 \%$. 


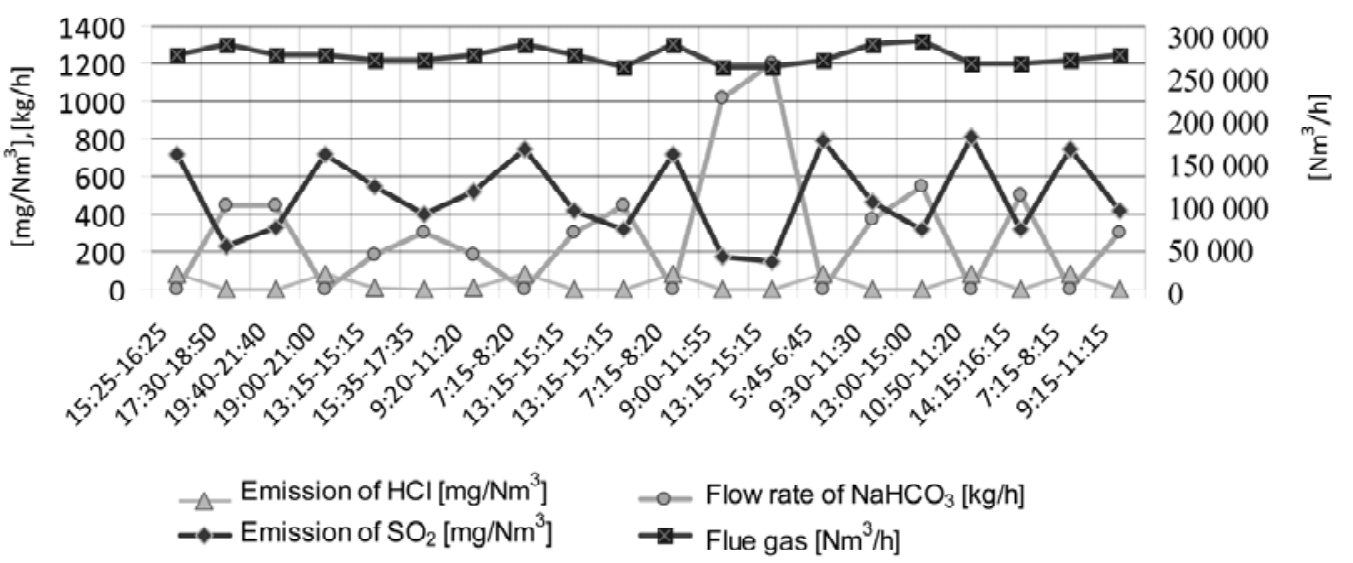

Fig. 4. Desulphurisation test results- $180 \mathrm{t} / \mathrm{h}$

With the $148858 \mathrm{Nm}^{3} / \mathrm{h}$ average flow rate of the combustion products at the $110 \mathrm{t} / \mathrm{h}$ furnace output level, and with the $724 \mathrm{mg} / \mathrm{Nm}^{3}$ average concentration of sulphur dioxide in the combustion products, the reference consumption of the sodium bicarbonate based agent needed to meet the 200 $\mathrm{mg} / \mathrm{Nm}^{3}$ emission limit was ca $439 \mathrm{~kg} / \mathrm{h}$. The reference stoichiometric ratio $2 \mathrm{Na} / \mathrm{S}$ equals to the value of 1.55. The value of the reference stoichiometric ratio $2 \mathrm{Na} / \mathrm{S}$ was determined on the basis of calculated and experimentally recorded figures. The longest period and the number of tests were conducted within the framework of the desulphurisation test at the $180 \mathrm{t} / \mathrm{h}$ steam output level. At the $180 \mathrm{t} / \mathrm{h}$ steam output level, with the $270000 \mathrm{Nm}^{3} / \mathrm{h}$ average flow rate, the average concentration of sulphur dioxide in combustion products amounting to $760 \mathrm{mg} / \mathrm{Nm}^{3}$, the reference consumption of the sodium bicarbonate based agent needed to meet the $200 \mathrm{mg} / \mathrm{m}_{\mathrm{N}}^{3}$ emission limit was ca $780 \mathrm{~kg} / \mathrm{h}$ (Fig. 5). The reference stoichiometric ratio $2 \mathrm{Na} / \mathrm{S}$ equals to the value of 1.47 .

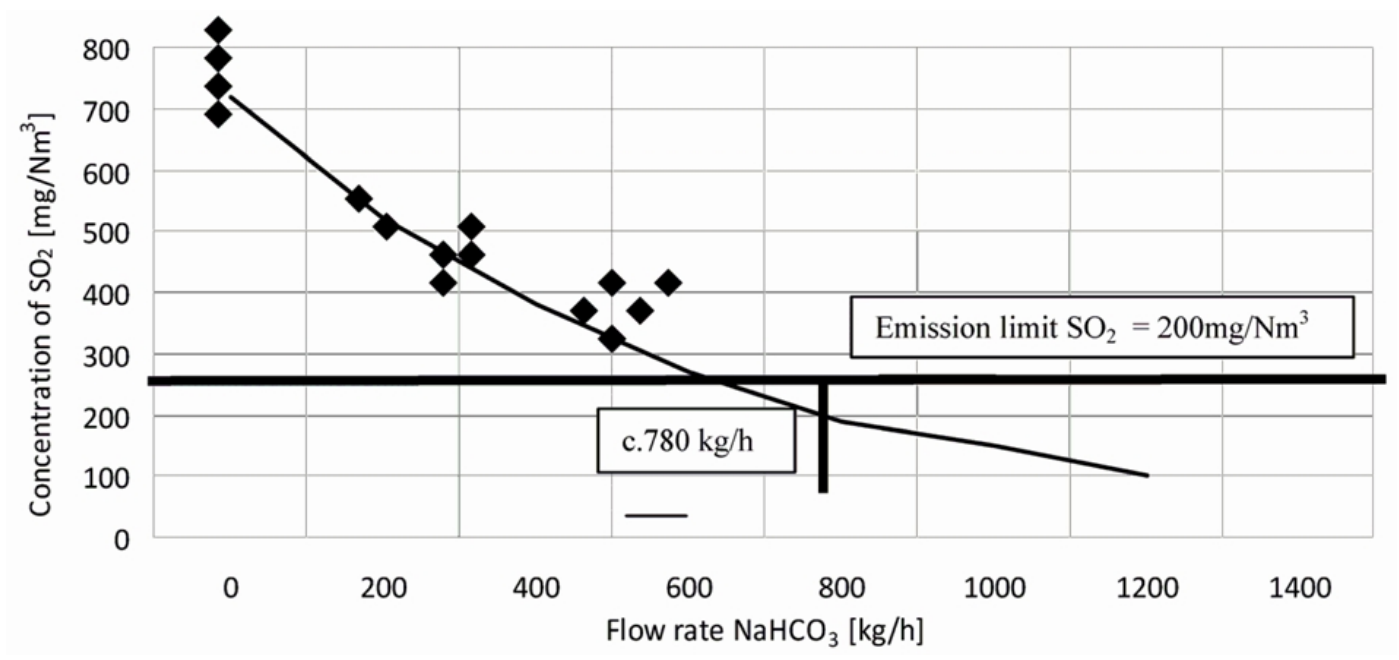

Fig. 5. Reduction of $\mathrm{SO}_{2}$ in dependence on the $\mathrm{NaHCO}_{3}$ flow $-180 \mathrm{t} / \mathrm{h}$

The value of the reference stoichiometric ratio $2 \mathrm{Na} / \mathrm{S}$ was determined on the basis of calculated and experimentally recorded figures presented in Fig.6. The conclusions are presented in Fig. 6, which shows the dependency of the desulphurisation level on the stoichiometric ratio $2 \mathrm{Na} / \mathrm{S}$. The final output of the experimental testing is recorded in the reference Fig. 7, which shows the dependency of the desulphurisation level on the stoichiometric ratio of all methods used in the Czech Republic, i.e. the dry method, the semi-dry method and the wet lime-cleaning method and the new method described in the article. The diagram includes the calculated values of dependency of the desulphurisation level on the stoichiometric ratio $2 \mathrm{Na} / \mathrm{S}$, i.e. the results of the dry-way desulphurisation using the sodium 
bicarbonate based agent. The possible ways of increasing desulphurisation efficiency with the sodium bicarbonate based agent may be summarise in the following points:

- The fine grain-size is a factor which enhances desulphurisation efficiency.

- Elimination of the friction losses in the transportation piping from the grinder to the agent blasting point to the lowest value possible.

- The blasting with flanges may be improved in order to achieve a better blending effect of the gaseous and the solid parts.

- A very significant factor influencing the acquired desulphurisation efficiency is the extension of the agent reaction time, and consequently possible adjustments of electrostatic fly-ash separator parameters.

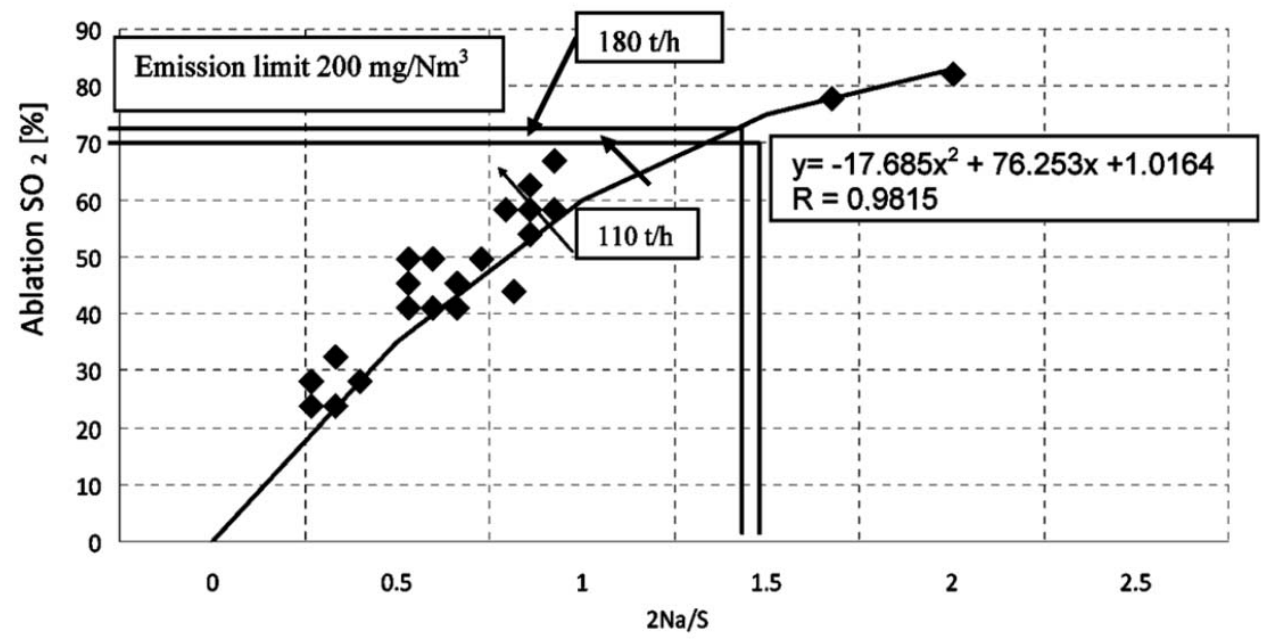

Fig. 6. The dependency of the level of desulphurisation on the stoichiometric ratio $2 \mathrm{Na} / \mathrm{S}$

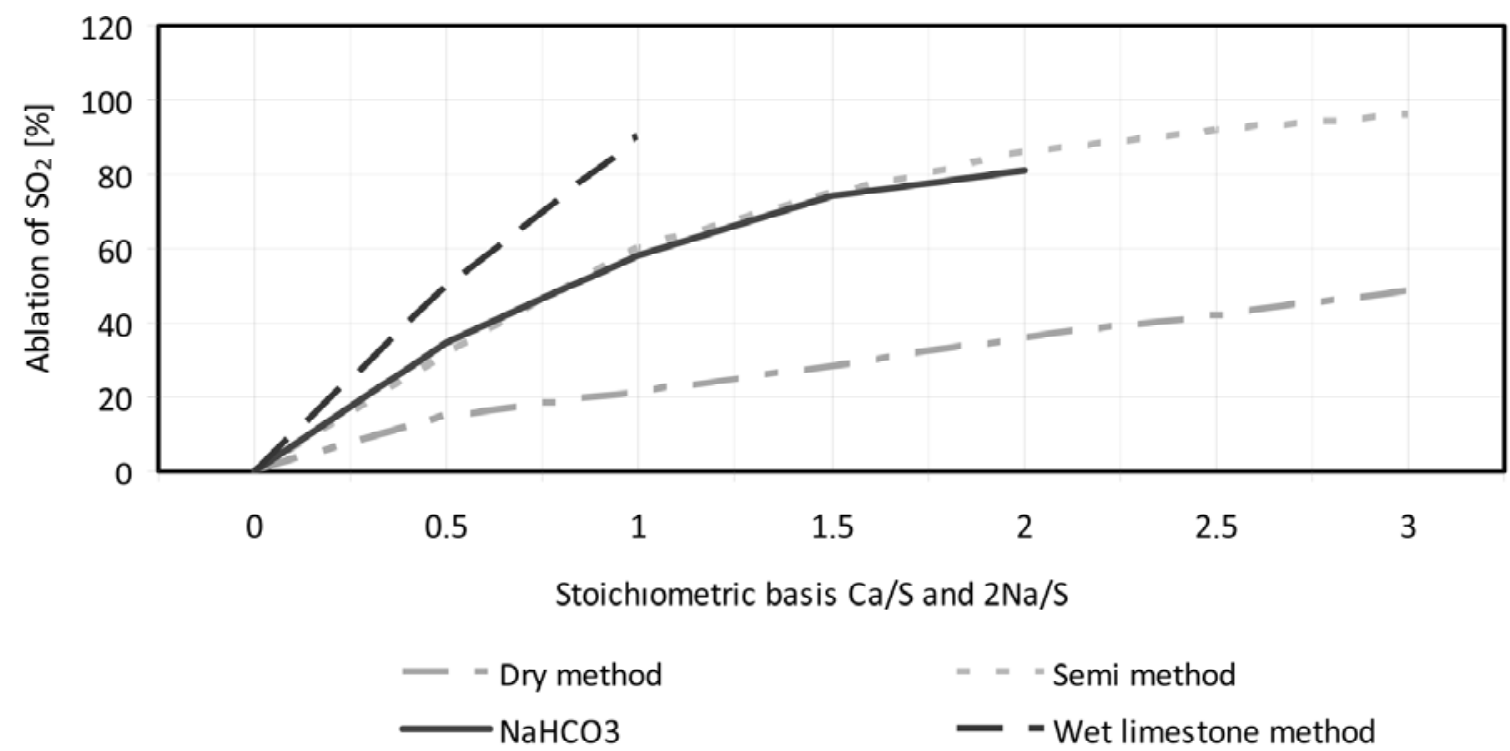

Fig. 7. The dependency of the level of desulphurisation on the stoichiometric ratio for individual methods and the new method by sodium bicarbonate described in the article

Dust emissions are determined by the particulate filter quality at the output of the boiler. In the case of the measured boiler the value guaranteed by the manufacturer of electrostatic filters is $100 \mathrm{mg} / \mathrm{Nm}^{3}$. 
During operation, the current value reaches $40-50 \mathrm{mg} / \mathrm{Nm}^{3}$. In the case of sodium bicarbonate application, an increase in the flow of solids in the filter is negligible without measurable effect (separation efficiency of 99.95\%). When using sodium bicarbonate, there are no serious corrosion problems. Basically, the flue gas tract operates only above the dew point. Utilisation of the desulphurisation product is limited and in the long term it is appropriate to store the product in underground coal mines.

During the desulphurisation process carbon dioxide is created. With regard to coal combustion this amount is negligible and does not affect significantly the total production of $\mathrm{CO}_{2}$. Similar problems are encountered in the calcium desulphurisation processes. The sodium bicarbonate desulphurisation process was promoted and introduced by the company SOLVAY in the Czech Republic. The first tests were carried out in the melting boiler Třebovice power plant. The presented method is applied in the Kolín power plant.

\section{EVALUATION}

The critical place of the desulphurisation technology (Galos et al., 2003; Meij et al., 1984) with the use of sodium bicarbonate dosing is represented by the resulting properties of the fly ash. Primarily, it is the concentration of sodium ions $\mathrm{Na}^{+}$and sulphate ions $\mathrm{SO}_{4}{ }^{2-}$. A high concentration of salts in the leach does not allow its deposit to be regularly fly-ash dumped.

due to the dissolved matters and possible pollution of underground waters. The final concentrations of the dissolved matter which are influenced by quite high solubility of the final products with the sodium sulphate content may be critical also from the ecotoxicity viewpoint (Maier et al., 1990). Desulphurisation processes are currently drawing much attention. Calcium-based methods have a limited use of final products. The methods based on sodium require storing the final product in discarded mines, where there is no danger of underground water contamination . The method described in the article is simple and fast to implement.

The authors would like to express their acknowledgements to the National Program of Research ENET - energy units for utilisation of non-traditional energy sources CZ.1.05/2.1.00/03.0069 for the financial support of this work.

\section{REFERENCES}

Galos K.A., Smakowski T.S., Szlugaj J., 2003. Flue-gas desulphurisation products from polish coal-fired powerplants. Appl. Energy, 75, 257-265. DOI: 10.1016/S0306-2619(03)00039-4.

Halstead W.D., Raask E., 1969. The behaviour of sulphur and chlorine compounds in pulverised coal-fired boilers. J. Inst. Fuel, 42, 344-349.

Joutsenoja T., 1998. Pyrometric thermometry and sizing of fuel particles in combustion. $\mathrm{PhD}$ Thesis, Tampere University of Technology, The Finland.

Lindner E.R., Wall T.F., 1990. Sodium ash reactions during combustion of pulverised coal. $23^{\text {rd }}$ Symposium (International) on Combustion. Orléans, France, 22-27 July 1990, 1313-1321. DOI: 10.1016/S00820784(06)80395-4.

Maier H., Schrofelbauer H., Filipot H., 1990. Process and device for the desulphurisation of flue gas from combustion plants. European Patent No. EP 0161497 (B1). European Patent Office.

Meij R., Van der Kooij J., Van der Sluys J.L.G., Siepman F.G.C., Van der Sloot H. A., 1984. Characteristics of emitted fly ash and trace elements from utility boilers fired with pulverised coal. KEMA Scientific \& Technical Reports 2 (1), Arnhem. 
Szeliga Z., Juchelkova D., Cech B., Kolat P., Winter F., Campen A.J, Wiltowski T.S., 2008. Potential of alternative sorbents for desulphurisation: from laboratory tests to the full-scale combustion unit. Energy fuels, 22, 3080-3088. DOI: 10.1021/ef800218t.

Uberoi M., Shadman F., 1990. Sorbents for the removal of lead compounds from hot flue gases. AICHE J., 36, 307-309. DOI: 10.1002/aic.690360220.

Received 11 April 2012

Received in revised form 17 December 2012

Accepted 19 December 2012 